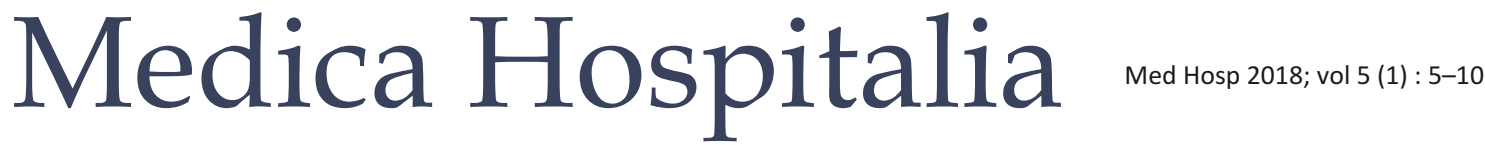

Original Article

\section{Hubungan Gambaran Hitung Jenis Leukosit Maternal dengan Korioamnionitis pada Ketuban Pecah Dini (Studi pada usia kehamilan 28-42 minggu)}

\author{
Hefie Rahmaniar ${ }^{1}$, Mochammad Besari Adi Pramono², Julian Dewantiningrum², \\ Herman Kristanto ${ }^{2}$, Nahwa Arkhaesi ${ }^{3}$ \\ ${ }^{1}$ Fakultas Kedokteran Universitas Diponegoro \\ ${ }^{2}$ Bagian Obstetri dan Ginekologi Fakultas Kedokteran Universitas Diponegoro/ RSUP Dr. Kariadi Semarang \\ ${ }^{3}$ Bagian Anak Fakultas Kedokteran Universitas Diponegoro/ RSUP Dr. Kariadi Semarang
}

\begin{abstract}
Abstrak
Latar belakang : Ketuban Pecah Dini (KPD) merupakan masalah obstetri yang dikaitkan dengan korioamnionitis. Diagnosis korioamnionitis ditegakkan secara histopatologis setelah kelahiran, sehingga perlu upaya deteksi dini untuk mencegah komplikasi lebih lanjut, misalnya dengan hitung jenis leukosit maternal. Penelitian ini bertujuan menganalisis hubungan gambaran hitung jenis leukosit maternal dengan korioamnionitis pada KPD.

Metode : Penelitian observasional analitik dengan rancangan belah lintang ini menggunakan 54 sampel KPD yang terbagi dalam korioamnionitis dan bukan korioamnionitis yang diambil dari data sekunder di beberapa rumah sakit di Jawa Tengah. Data meliputi karakteristik pasien dan hitung jenis leukosit. Analisis data ditampilkan dalam bentuk frekuensi dan persentase, serta rerata dan simpang baku atau median dan nilai maksimum dan minimum. Uji hipotesis dianalisis dengan uji T-tidak berpasangan dan uji Mann-Whitney.

Hasil : Pasien korioamnionitis memiliki hasil perhitungan lebih tinggi pada hitung leukosit total (sel/ $\mu \mathrm{l}: 13243.7$ vs 9790; $p=0,032)$, basofil $(24,5$ vs $18.13 ; p=0,020)$, neutrofil $(9495,33$ vs $7907 ; p=0,020)$, dan monosit $(735,59$ vs 529,$54 ; p=0,008)$. Hasil lain adalah eosinofil $(53,6$ vs $73.04 ; p=0,849)$ dan limfosit $(1880,56$ vs 1525,$65 ; p=0,684)$.
\end{abstract}

Simpulan : Terdapat hubungan antara hitung leukosit total, neutrofil, basofil, dan monosit dengan korioamnionitis pada KPD.

Kata kunci : KPD, korioamnionitis, hitung jenis leukosit

\section{The correlations between maternal leukocyte differential counting and chorioamnionitis in premature rupture of membrane (The study of gestational age of 28-42 weeks)}

\author{
Abstract
}

Background : Premature Rupture Of Membrane (PROM) is an obstetrical problem which is related to chorioamnionitis. Chorioamnionitis is diagnosed by means of histopathological approach after delivery, therefore an early detection method, such as maternal leukocyte differential counting, is important to prevent from further complications. This study was aim to analyze the correlations between maternal leukocyte differential counting and chorioamnionitis in PROM.

Methods : This observational analytic research with crosssectional study involved 54 samples of PROM, divided into chorioamnionitis and non korioamnionitis, whose data was taken from secondary data at several hospitals in Central Java. The data was consisted of patients' characteristics and differential counting, which were described in form of frequency and percentage, mean and standard deviation, or median and minimum-maximum value. The hypothesis was based on unpaired T-test and Mann-Whitney U test.

Results : The patients with chorioamnionitis had higher leukocytecounts (sel/ $\mu$ l: 13243.7 vs $9790 ; p=0.032$ ), basophil ( 24.5 vs $18.13 ; p=0.020)$, neutrophil (9495.33 vs 7907; $p=0.020$ ), and monocyte ( 735.59 vs $529.54 ; p=0.008$ ). Then, the other data was eosinophil (53.6 vs $73.04 ; p=0.849$ ) dan lymphocyte counts (1880.56 vs $1525.65 ; p=0.684$ ). 
Conclusion : There are correlations between total leukocytes counts, neutrophil, basophil, and monocyte with chorioamnionitis in PROM.

Keywords : PROM, chorioamnionitis, leukocyte differential counting

\section{PENDAHULUAN}

Ketuban Pecah Dini (KPD) masih menjadi salah satu masalah penting dalam bidang obstetri yang meningkatkan morbiditas dan mortalitas maternal dan neonatal. Menurut data Departemen Kesehatan Republik Indonesia, KPD di Indonesia terjadi sebanyak 6-10\% dari seluruh kelahiran sepanjang tahun 2010, dengan kejadian pada kehamilan aterm sebanyak $95 \%$ dan pada kehamilan preterm 34\%. ${ }^{1}$ Etiologi KPD belum dapat dijelaskan secara pasti, namun kejadiannya sering dikaitkan dengan korioamnionitis, yaitu keadaan pada wanita hamil di mana korion, amnion, dan cairan ketuban terkena infeksi bakteri. ${ }^{2}$ Selain pengaruh toksin yang dihasilkan oleh antigen seperti protease dan kolagenase, reaksi imunologis yang muncul akibat paparan juga mampu menjelaskan mekanisme terjadinya korioamnionitis. Keduanya dapat mengganggu integritas matriks ekstraseluler yang didominasi oleh kolagen. ${ }^{3,4}$ Sayangnya, korioamnionitis baru dapat didiagnosis pasca persalinan melalui pemeriksaan histopatologis. Sulit untuk mendiagnosis secara klinis adanya korioamnionitis karena gejalanya yang tidak khas. ${ }^{5,6}$ Namun, deteksi dini perlu dilakukan untuk menangani lebih lanjut dan mencegah perkembangannya dari fase subklinis menjadi fase klinis, misalnya dengan melakukan pemeriksaan leukosit maternal. Adanya leukositosis merupakan suatu penanda yang umum terjadinya infeksi dalam tubuh, di mana perbandingan jenis-jenis leukosit dapat menjadi penanda yang lebih spesifik, sehingga pola penyakit dapat diketahui lebih lanjut. ${ }^{7,8}$ Selain itu, pemeriksaan ini pun mudah dilakukan dan dapat diaplikasikan di layanan primer.

Permasalahan pada penelitian ini adalah apakah ada hubungan gambaran hitung jenis leukosit maternal dengan korioamnionitis pada ketuban pecah dini. Sedangkan, tujuan dari penelitian ini adalah menganalisis hubungan gambaran hitung jenis leukosit maternal dengan korioamnionitis pada ketuban pecah dini.

\section{METODE}

Penelitian ini adalah penelitian observasional analitik dengan rancangan belah lintang (cross sectional). Penelitian ini menggunakan data sekunder yang dilaksanakan di Bagian/KSM Obstetri dan Ginekologi
Fakultas Kedokteran Universitas Diponegoro RSUP Dr. Kariadi Semarang serta rumah sakit lain yang menyetujui penelitian ini, antara lain Rumah Sakit Nasional Diponegoro Semarang, RSUD Dr. Adhyatma, MPH Semarang, RSUD K.R.M.T Wongsonegoro Semarang, RSIA Bunda Semarang, RSUD Prof. Dr. Margono Soekarjo Purwokerto, RSUD Dr. Soeselo Slawi, serta RSUD R.A. Kartini Jepara, dan Bagian/ KSM Patologi Anatomi Fakultas Kedokteran Universitas Diponegoro RSUP Dr. Kariadi Semarang. Waktu penelitian dimulai sejak bulan Februari hingga Juni 2017.

Sampel penelitian adalah ibu hamil pada usia kehamilan 28-42 minggu dengan ketuban pecah dini yang telah melahirkan di rumah sakit tempat penelitian pada periode penelitian yang memenuhi kriteria. Kriteria inklusi pada penelitian ini antara lain ibu hamil pada usia kehamilan 28-42 minggu dengan ketuban pecah dini, belum masuk fase persalinan, janin tunggal hidup intrauterin, dan bersedia mengikuti penelitian. Sementara, kriteria eksklusinya antara lain ibu hamil dengan penyakit penyulit lain (seperti penyakit hipertensi dalam kehamilan, penyakit ginjal, penyakit hati, penyakit infeksi kronis, penyakit jantung, penyakit diabetes mellitus, anemia dengan $\mathrm{Hb}<7 \mathrm{gr} \%$, serta keganasan), memiliki riwayat trauma selama kehamilan, hidramnion, makrosomia, inkompetensi serviks, persalinan dengan bantuan vacuum/forceps, dan ketuban pecah dini yang dilakukan konservatif.

Pemilihan subyek penelitian dilakukan secara consecutive sampling, yaitu berdasarkan kedatangan subyek penelitian di rumah sakit tempat penelitian. Berdasarkan rumus besar sampel didapatkan 54 subyek penelitian yang terbagi dalam kelompok korioamnionitis dan bukan korioamnionitis. Pengumpulan data menggunakan data sekunder yang berisi identitas subyek penelitan, anamnesis, pemeriksaan fisik termasuk diagnosis KPD menggunakan tes lakmus, data hitung jenis leukosit, dan data diagnosis korioamnionitis secara histopatologis.

Analisis data meliputi analisis deskriptif tentang karakteristik subyek penelitian yang dinyatakan dalam frekuensi dan persentase, serta uji hipotesis dengan uji T-tidak berpasangan pada data yang berdistribusi normal dan uji Mann-Whitney pada data yang berdistribusi tidak normal. Penelitian ini telah mendapat persetujuan dari Komisi Etik Penelitian Kesehatan Fakultas Kedokteran Universitas Diponegoro No. 20/EC/FK-RSDK/1/2017. 


\section{TABEL 1}

\section{Karakteristik subyek penelitian}

\begin{tabular}{|c|c|c|c|c|c|}
\hline \multirow[t]{2}{*}{ Karakteristik } & & \multicolumn{2}{|c|}{$\begin{array}{l}\text { Korioamnionitis } \\
\text { (27 subyek) }\end{array}$} & \multicolumn{2}{|c|}{$\begin{array}{c}\text { Bukan Korioamnionitis } \\
\text { (27 subyek) }\end{array}$} \\
\hline & & $n$ & $\%$ & $\mathbf{n}$ & $\%$ \\
\hline \multirow[t]{3}{*}{ Usia } & $<20$ tahun & 4 & 14,8 & 2 & 7,4 \\
\hline & 20-35 tahun & 17 & 63,0 & 18 & 66,7 \\
\hline & $>35$ tahun & 6 & 22,2 & 7 & 25,9 \\
\hline \multirow[t]{4}{*}{ Pendidikan } & Tidak sekolah & 0 & 0 & 0 & 0 \\
\hline & SD-SMP & 15 & 55,6 & 13 & 48,1 \\
\hline & SMA & 10 & 37,0 & 10 & 37,0 \\
\hline & PT & 2 & 7,4 & 4 & 14,8 \\
\hline \multirow[t]{3}{*}{ Pendapatan } & Rp 500 ribu - 2,2 juta & 17 & 63,0 & 18 & 66,7 \\
\hline & Rp 2,2 juta - 5 juta & 8 & 29,6 & 6 & 22,2 \\
\hline & Rp $>5$ juta & 2 & 7,4 & 3 & 11,1 \\
\hline \multirow[t]{5}{*}{ Pembiayaan } & BPJS PBI & 12 & 44,4 & 8 & 29,6 \\
\hline & BPJS Non PBI & 9 & 33,3 & 8 & 29,6 \\
\hline & BPJS Kelas $2 / 3$ & 3 & 11,1 & 7 & 25,9 \\
\hline & Umum & 2 & 7,4 & 2 & 7,4 \\
\hline & Asuransi & 1 & 3,7 & 2 & 7,4 \\
\hline \multirow[t]{3}{*}{ Paritas } & Nuliparitas & 10 & 37,0 & 8 & 29,6 \\
\hline & Multiparitas & 16 & 59,3 & 19 & 70,4 \\
\hline & Grande multiparitas & 1 & 3,7 & 0 & 0 \\
\hline \multirow[t]{2}{*}{ Usia kehamilan } & $<37$ minggu & 13 & 48,1 & 16 & 59,3 \\
\hline & $\geq 37$ minggu & 14 & 51,9 & 11 & 40,7 \\
\hline \multirow[t]{5}{*}{ Lama KPD } & $<6$ jam & 6 & 22,2 & 2 & 7,4 \\
\hline & 6-12 jam & 10 & 37,0 & 14 & 51,9 \\
\hline & 12-24 jam & 9 & 33,3 & 7 & 25,9 \\
\hline & 24-48 jam & 2 & 7,4 & 1 & 3,7 \\
\hline & $>48$ jam & 0 & 0 & 3 & 11,1 \\
\hline \multirow[t]{2}{*}{ Riwayat KPD } & Ya & 2 & 7,4 & 7 & 25,9 \\
\hline & Tidak & 25 & 92,6 & 20 & 74,1 \\
\hline \multirow[t]{2}{*}{ Riwayat keputihan } & Ya & 8 & 29,6 & 4 & 14,8 \\
\hline & Tidak & 19 & 70,4 & 23 & 85,2 \\
\hline \multirow[t]{2}{*}{ Riwayat perdarahan } & Ya & 2 & 7,4 & 1 & 3,7 \\
\hline & Tidak & 25 & 92,6 & 26 & 96,3 \\
\hline
\end{tabular}




\begin{tabular}{|c|c|c|c|}
\hline \multicolumn{4}{|c|}{ Hubungan hitung jenis leukosit dengan korioamnionitis } \\
\hline Variabel & Korioamnionitis & Bukan Korioamnionitis & $\boldsymbol{p}$ \\
\hline Leukosit total (sel/ $\mu \mathrm{l})$ & $12570(8460-20620)^{b}$ & $9790(6800-21000)^{b}$ & $0,032^{c}$ \\
\hline Eosinofil (sel/ $\mu \mathrm{l})$ & $53,6(0-446)^{b}$ & $73,04(0-679)^{b}$ & $0,849^{c}$ \\
\hline 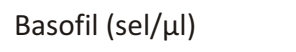 & $24,58 \pm 10,92^{\mathrm{a}}$ & $18,13 \pm 8.81^{a}$ & $0,020^{d}$ \\
\hline Neutrofil (sel/ul) & $9495,33(6159-17500)^{b}$ & $7907(4786-18060)^{b}$ & $0,020^{c}$ \\
\hline Limfosit (sel/ul) & $1908(858-2916)^{b}$ & $1525,65(717-4472)^{b}$ & $0,684^{\mathrm{c}}$ \\
\hline Monosit (sel/ $\mu \mathrm{l})$ & $755,08(264-1260)^{b}$ & $529,54(218-1143)^{b}$ & $0,008^{c}$ \\
\hline
\end{tabular}

\section{HASIL}

Tabel 1 menunjukkan karakteristik subyek penelitian. Tabel 2 menunjukkan hubungan hitung jenis leukosit dengan korioamnionitis pada KPD.

Hitung leukosit total pada kelompok korioamnionitis memiliki nilai median $12570 \mathrm{sel} / \mu \mathrm{l}$ dengan rentang minimum-maksimum 8460-20620 sel/ $\mu \mathrm{l}$ lebih tinggi dibanding kelompok bukan korioamnionitis, yaitu nilai median $9790 \mathrm{sel} / \mu \mathrm{l}$ dengan jumlah sel 6800 sel/ $\mu 1$ hingga 21000 sel/ $\mu 1$. Hitung eosinofil menunjukkan rentang yang lebih besar pada kelompok bukan korioamnionitis. Hitung basofil pada kelompok korioamnionitis memiliki nilai rata-rata lebih tinggi. Pada hitung neutrofil, nilai median dan minimum kelompok korioamnionitis lebih tinggi dibanding kelompok bukan korioamnionitis, namun nilai maksimumnya lebih rendah. Sementara itu, pada hitung limfosit maupun monosit, didapatkan nilai ukuran pemusatan yang lebih tinggi pada kelompok korioamnionitis dibanding kelompok bukan korioamnonitis.

Secara statistik dengan nilai kemaknaan $p<0,05$, perbedaan yang bermakna antara korioamnionitis dan bukan korioamnionitis ditunjukkan oleh hitung leukosit total $(p=0,032)$, basofil $(p=0,020)$, neutrofil $(p=0,020)$, dan monosit $(p=0,008)$. Sedangkan, eosinofil $(p=0,849)$ dan limfosit $(p=0,684)$ menunjukkan perbedaan yang tidak bermakna.

\section{DISKUSI}

Pada penelitian ini, didapatkan leukosit total yang lebih tinggi pada korioamnionitis dibanding dengan bukan korioamnionitis. Hasil ini sesuai beberapa penelitian sebelumnya, yaitu penelitian Kim dan Alan, yang menyatakan bahwa korioamnionitis secara histopatologis erat hubungannya dengan hitung jumlah leukosit dan neutrofilia. ${ }^{9,10}$ Hubungan yang saling mempengaruhi terjadi antara adanya infeksi korioamnion, KPD, dan peningkatan leukosit maternal. Infeksi korioamnion dapat secara langsung menurunkan integritas selaput ketuban atau berpengaruh terhadap respon inflamasi maternal yang selanjutnya dapat menyebabkan KPD. Sebaliknya, adanya KPD dapat menjadi faktor risiko terjadinya korioamnionitis yang akan berpengaruh terhadap peningkatan leukosit maternal.

Korioamnionitis terjadi akibat invasi bakteri ke lingkungan intraamnion dari traktus urogenitalis secara asendens atau pada kasus yang lebih jarang, infeksi dapat berasal dari sistemik. ${ }^{11}$ Kemudian, akan terjadi suatu respon lokal berupa peningkatan permeabilitas pembuluh darah yang memungkinkan leukosit keluar menuju jaringan yang terinfeksi. Jumlah leukosit akan terus meningkat akibat pengaruh komplemen C3a dan C5a hingga proses "pembersihan" dirasa cukup. Peningkatan ini membuat jumlah leukosit dalam darah bertambah karena perpindahan leukosit dari tempat produksi atau penyimpanannya menuju lokasi jejas melalui aliran darah. Inilah yang disebut sebagai leukositosis.Adanya leukosit sebagai sel inflamasi dapat memproduksi ROS sebagai bakterisidal. Produksi ROS ini akan meningkatkan aktivitas MMP yang berperan dalam degradasi matriks ekstrasel selaput ketuban melalui mekanisme katabolisme kolagen. Kenaikan MMP yang tidak diimbangi dengan kenaikan TIMP sebagai inhibitornya, akan menyebabkan terjadinya KPD. $8,9,12,13$

Sebaliknya, selaput ketuban merupakan sawaryang memisahkan lingkungan intra amnion dengan lingkungan ekstra amnion untuk melindungi janin dari infeksi dan trauma secara langsung serta menyediakan tempat yang tepat untuk pertumbuhan 
dan perkembangan janin., ${ }^{2,14}$ Tanpa adanya sawar akibat terjadinya KPD, invasi mikroorganisme ke lingkungan intra amnion akan semakin mudah terjadi. Invasi ini akan dimulai dari titik awal pecahnya selaput ketuban, kemudian meluas ke pembuluh darah janin (koriovaskulitis), dan berlanjut ke lingkungan intra amnion (amnionitis) hingga menginfeksi janin secara sistemik. Selain berpengaruh terhadap lingkungan janin, infeksi juga akan menyebar ke desidua, serviks, dan vagina. Inilah yang menyebabkan terjadinya leukositosis maternal. ${ }^{11}$

Selain itu, didapatkan pula hasil yang signifikan dan data hitung yang lebih tinggi pada hitung neutrofil. Respon imun tubuh yang kuat berupa peningkatan produksi sitokin dan kemokin pro inflamasi seperti IL-1, IL-6, IL-10, tumor necrosis factor-a (TNF-a), granulocyte colony-stimulating factor (G-CSF), prostaglandin, dan leukotrien, pada akhirnya menjadi penyebab timbulnya neutrofilia. ${ }^{9}$ Oleh karena itu, pada korioamnionitis yang agen infeksinya adalah bakteri dan bersifat akut, leukosit jenis PMN adalah yang paling terpengaruh, terutama neutrofil.

Secara statistik, tidak terdapat perbedaan limfosit yang bermakna antara korioamnionitis dengan bukan korioamnionitis. Hasil ini sesuai dengan penelitian Wui di mana tidak terdapat perbedaan yang signifikan pada hitung limfosit, ${ }^{15}$ namun berlainan dengan penilitian Kim yang menyatakan bahwa terdapat perbedaan yang signifikan, di mana hitung limfosit lebih rendah pada KPD dengan infeksi dibanding dengan KPD non infeksi. ${ }^{9}$ Pada infeksi yang bersifat akut, pertahanan tubuh yang pertama kali digunakan adalah sistem imun non spesifik atau dengan kata lain, penggunaan sistem imun spesifik ditunda selama sistem imun non spesifik masih bisa mengatasi infeksi. Apabila penggunaan sistem imun non spesifik tidak mampu lagi untuk menanggulangi terjadinya infeksi, maka pertahanan tubuh akan beralih menjadi sistem imun spesifik, sehingga terjadi limfositosis. ${ }^{7,8,16}$ Yang terjadi pada korioamnionitis yang merupakan infeksi akut adalah limfopenia karena limfosit termasuk dalam sistem imun spesifik atau bisa juga terjadi limfopenia relatif akibat efek masking dari peningkatan neutrofil. ${ }^{16}$ Mekanisme inilah yang menjelaskan mengapa pada penelitian ini hitung limfosit tidak menunjukkan perbedaan yang signifikan antara korioamnionitis dan bukan korioamnionitis. Selain itu, inflamasi akan menginduksi adanya gangguan pada presentasi antigen, mengaktivasi sinyal ko-stimulasi negatif, serta memproduksi faktor-faktor imunosupresif. Ketiganya ini berkontribusi pada penurunan signifikan dari jumlah limfosit T-helper. Pada infeksi akut juga terdapat peningkatan TNF yang meningkatkan reseptor pada limfosit T-helper, namun juga menyebabkan apoptosis limfosit T-sitotoksik. ${ }^{9,17}$

Terdapat perbedaan yang signifikan pada hitung monosit dan basofil antara korioamnionitis dan bukan korioamnionitis. Peningkatan monosit dapat terjadi karena monosit berperan dalam fagositosis dan APC. Monosit, yang kemudian dapat berdiferensiasi menjadi makrofag jaringan, aktivasinya dimulai ketika terdapat kontak antara antigen dengan reseptor. Aktivasi selanjutnya dapat dipacu oleh sitokin yang dilepaskan mediator inflamasi dan sel Th. Sehingga, semakin banyak aktivasi, semakin banyak pula monosit yang bermigrasi ke jaringan untuk menjadi makrofag jaringan melalui darah atau disebut sebagai monositosis. Begitu pun yang terjadi pada peningkatan basofil, di mana basofil berperan dalam pelepasan mediator inflamasi, seperti histamin, heparin, dan leukotrien, yang mampu meningkatkan permeabilitas vaskular dan mengundang semakin banyak leukosit ke tempat terjadinya jejas. ${ }^{8,16,17}$

Sementara, tidak terdapat perbedaan yang signifkan pada hitung eosinofil yang berperan sebagai fagosit dan dapat mengalami degranulasi untuk melepaskan mediator inflamasi, seperti pada basofil. Namun, fungsinya lebih aktif pada imunitas terhadap infeksi parasit serta berespon kuat terhadap IgE. ${ }^{8,16,17}$

Penelitian ini memiliki keterbatasan dalam cara pengumpulan sampel karena tidak semua data sekunder yang ada lengkap dan dapat digunakan. Selain itu, masih mungkin terdapat bias dalam pembuatan preparat PA, sehingga berpengaruh terhadap diagnosis histopatologisnya. Tidak adanya data tentang upaya pemberian antibiotik pada KPD juga mempengaruhi kemungkinan terjadinya salah interpretasi pada hitung jenis leukosit.

\section{SIMPULAN}

Terdapat hubungan antara hitung leukosit total, neutrofil, basofil, dan monosit dengan korioamnionitis pada ketuban pecah dini, di mana nilai pada korioamnionitis lebih tinggi dibanding bukan korioamnionitis.

Pada penelitian selanjutnya diharapkan dapat menggunakan data yang lebih lengkap dan rinci, dapat dilakukan penelitian dengan desain yang berbeda, misalnya case control, untuk mengetahui proses kejadian penyakit, serta dapat diberlakukan standarisasi pemotongan sampel kulit ketuban untuk mengurangi bias dalam diagnosis histopatologis.

\section{DAFTAR PUSTAKA}

1. Sari EK, Juaria H. Hubungan Paritas dan Kelainan Letak dengan Kejadian Ketuban Pecah Dini. J Akad Kebidanan Griya Husada. 2013;21(110):1-9.

2. Sarwono P. Ilmu Kebidanan. $4^{\text {th }}$ ed. Saifuddin AB, Rachmihadhi T, Wiknjosastro GH, editors. Jakarta: PT Bina Pustaka Sarwono Prawirohardjo; 2009.677-682p.

3. Goldenberg RL, Culhane JF, Iams JD, Romero R. Preterm Birth I: Epidemiology and Causes of Preterm Birth. Lancet. 2008;371:75-84. 
4. Sudiarta I. Bakteriuri asimtomatis meningkatkan risiko terjadinya ketuban pecah dini preterm. 2014;1-54.

5. Park C-W, Yoon BH, Park JS, Jun JK. An elevated maternal serum C-reactive protein in the context of intra-amniotic inflammation is an indicator that the development of amnionitis, an intense fetal and AF inflammatory response are likely in patients with preterm labor: clinical implications. J Matern Fetal Neonatal Med. 2013;26(9):847-53.

6. Burke C, Chin EG. Chorioamnionitis at Term. J Perinat Neonatal Nurs. 2016;30(2):106-14.

7. Sherwood L. Fisiologi Manusia: Dari Sel ke Sistem. $8^{\text {th }}$ ed. Ong HO, Mahode AA, Ramadhani D, editors. Jakarta: EGC; 2014. $425-430 \mathrm{p}$.

8. Abbas AK, Lichtman AH. Basic Immunology Functions and Disorders of The Immune System. $3^{\text {rd }}$ ed. Philadelphia: Saunders; 2011.

9. Kim MA, Lee YS, Seo K. Assessment of predictive markers for placental inflammatory response in preterm births. PLoS One. 2014;9(10).

10. Tita A, Andrews W. Diagnosis and Management of Clinical Chorioamnionitis. Clin Perinatol. 2010;37(2):339-54.

11. Raudah A, Jannah A, Sophia A, Agustina EER, Putri IC, Fatimah S. Infeksi Intra Uterine dan Persalinan Preterm. FKIK UIN Syarif Hidayatullah. 2010;1-33.
12. Sudiarta I. Bakteriuri asimtomatis meningkatkan risiko terjadinya ketuban pecah dini preterm. 2014;1-54.

13. Jaya M. Peningkatan Jumlah Neutrofil pada Sekret Vagina berhubungan dengan Tingginya Persalinan Preterm. Fak Kedokt Univ Udayana. 2013.

14. Cunningham FG, Leveno KJ, Bloom SL, Spong CY, Dashe JS, Hoffman BL, et al. Williams Obstetrics. 24 $4^{\text {th }}$ ed. McGraw-Hill Education; 2014. 231-239p.

15. Wu HC, Shen CM, Wu YY, Yuh YS, Kua KE. Subclinical Histologic Chorioamnionitis and Related Clinical and Laboratory Parameters in Preterm Deliveries. Pediatr Neonatol. 2009;50(5):217-21.

16. Baratawidjaja KG, Renggana I. Imunologi Dasar. $10^{\text {th }}$ ed. Jakarta: Badan Penerbit FKUI; 2012. 62-79 p.

17. Levinson W. Review of Medical Microbiology and Immunology. Vol. 1, The effects of brief mindfulness intervention on acute pain experience: An examination of individual difference. 2014.1195-1202p. 